\title{
Relationship between Reading Proficiency, Strategic Competence, and Reading Comprehension Test Performance: A Study of Iranian EFL Learners
}

\author{
Narjes Ghafournia ${ }^{1} \&$ Akbar Afghari ${ }^{1}$ \\ ${ }^{1}$ Department of Foreign Languages, Khorasgan Branch, Islamic Azad University, Isfahan, Iran \\ Corresponding Author: Narjes Ghafournia, Department of Foreign Languages, Khorasgan Branch, Islamic Azad \\ University, Isfahan, Iran. Tel: 98-915-313-0060. E-mail: narjesghafournia@yahoo.com
}

Received: May 19, 2013 Accepted: June 28, $2013 \quad$ Online Published: July 16, 2013

doi:10.5539/ies.v6n8p21 URL: http://dx.doi.org/10.5539/ies.v6n8p21

\begin{abstract}
The study scrutinized the interaction between reading proficiency and strategic competence via reading comprehension test performance of Iranian EFL learners. The further concern was to scrutinize the extent to which strategic competence affected the participants' test performance. The participants were 506 postgraduate students who took a reading comprehension test and answered a metacognitive strategy questionnaire successively in one session. The findings manifested that the participants at the high level of reading proficiency used metacognitive strategies more frequently than did the participants at the low and intermediate levels of reading proficiency in the test-taking setting. The findings also revealed a positive linear relationship between metacognitive awareness and the participants' test performance. The findings provide empirical evidences for the close interaction between linguistic and strategic competences, as the two major components of communicative language ability, discussed in different frameworks for language use such as Bachman's (1990) and Bachman and Palmer's (1996) frameworks. The findings revealed the necessity for designing the instructional programs focusing on both linguistic and strategic aspects of language learning in a balanced way to improve reading ability of L2 learners. The findings indicate that the true score of language learners is dependent on linguistic and strategic aspects of test-taking. Thus, the findings recommend language teachers to interpret test scores with great care to make fair decisions about the actual ability of test takers. In addition, the findings encourage curriculum planners and language teachers to design appropriate instructional materials and adapt effective teaching approaches to improve reading comprehension.
\end{abstract}

Keywords: communicative competence, linguistic competence, strategic competence, metacognitive awareness, true score

\section{Introduction}

Most of the studies on second language reading manifested that second language learners use a set of competencies for effective reading comprehension (e.g. Brantmeier, 2002; Liontas, 2002; Saricoban, 2002; Scarcella \& Oxford, 1992; Shrum \& Glisan, 2000; Singhal, 2001). The four major competences are grammatical competence, sociolinguistic competence, discourse competence, and strategic competence, assisting second language learners in accomplishing a multitude of reading tasks. Since the development of cognitive psychology in 1970s, strategic competence has got wider significance encouraging many researchers to work on the underlying strategic process of language learning and test taking (e.g. Cohen \& Dörnyei, 2002; Dreyer \& Oxford, 1996; Peacock \& Ho, 2003; Su, 2005). Bachman (1990) described strategic competence as an essential aspect of communicative language ability consisting of assessment, planning, and execution strategies. Bachman's description of strategic competence is more dynamic than the earlier descriptions dealing with the compensatory functions of strategic competence, particularly in interlanguage settings (e.g. Canale, 1983; Canale \& Swain, 1980: Farech \& Kasper, 1983). Bachman and Palmer $(1996,2010)$ considered strategic competence as a set of metacognitive components functioning in higher executive processes, providing cognitive management function in language use and the other cognitive activities. Bachman and Palmer also believed that strategic competence consists of a set of metacognitive strategies concerned with planning, monitoring, and evaluating language learners' problem-solving activities. The view is largely derived from Steinberg's description of the metacomponents in his model of intelligence (see Steinberg, 1985, 1988). 
The central role of strategic competence in communication activities has been depicted in Bachman and Palmer's $(1996,2010)$ conceptual frameworks of language use. Strategic competence acts as the major component, linking the individual characteristics of language users, including language knowledge, topical knowledge, personal characteristics, and affective schemata to the characteristics of language use settings. The two frameworks demonstrate an interaction among areas of language ability, topical knowledge, affective schemata, on the one hand, and the interaction between the mentioned attributes and the characteristics of language use setting through strategic competence, on the other. Strategic competence consists of a set of metacognitive strategies interacting with a language user's language knowledge, topical knowledge, affective schemata, and the characteristics of a language use task to achieve a communicative language purpose.

The key role of strategic competence has been also depicted in Bachman's (1990) classical framework for the components of communicative language ability as the mediating component, linking language competence to language users' knowledge structures and the features of the context in which communication takes place. Thus, language competence and strategic competence act as the two major components of language ability, the combination of which provides language users with the ability to create and interpret discourse in terms of the context requirements.

Thus, the present study was an attempt to explore the probable significant interaction between linguistic and strategic competences via reading comprehension test performance of Iranian EFL learners with regard to their level of reading proficiency. As improving reading comprehension is of primary importance in most of the academic English language teaching programs at universities, particularly at postgraduate level, the study was conducted in the area of reading comprehension with a number of postgraduate students doing EAP (English for Academic Purposes) courses in Iran. The further concern was to scrutinize the degree to which the participants' metacognitive awareness and reading test performance was related.

The findings can be significant due to comparing and contrasting metacognitive strategic patterns of language learners at different levels of reading proficiency revealing the gap between more proficient and less proficient learners. In addition, the findings can show the strength of the relationship between linguistic and strategic competences and the degree of variance in the test performance due to the effect of metacognitive strategies. Thus, the findings can help language teachers interpret test scores with great care to decrease error of measurement. The findings can provide useful information helping curriculum planners, syllabus designers, and language teachers design effective instructional programs to improve reading ability of L2 learners. The findings can remind language teachers of the strategic aspects of language learning and test taking that should be incorporated in language teaching programs. The findings can provide empirical evidence for classical frameworks of Bachman (1990) as well as Bachman and Palmer (1996), which have been rarely investigated systematically, particularly in reading comprehension test-taking settings.

\section{Literature Review}

Purpura (1997) worked on Bachman's (1990) classical framework of language use and considered strategic competence as a set of metacognitive strategies divided into the three groups of planning, monitoring, and evaluating strategies. Planning strategies are applied for future actions and goal attainment. Good examples of planning strategies are goal setting, overseeing tasks, and planning future actions beforehand. Planning strategies regulate test takers' thinking process to allocate resources, determine the order of the steps, and set the intensity or the speed of accomplishing a task. Monitoring strategies refer to the strategies used for checking ongoing comprehension or ongoing performance such as noticing comprehension failure and double-checking comprehension. Monitoring strategies are test takers' deliberate actions required to identify a current task, check the current progress of accomplishing the task, monitor their thinking and performance, and predict the outcome of the progress. Evaluating strategies are used for evaluating the past and current actions. Good examples of evaluating strategies are assessing the difficulty level of language task, checking the progress, and evaluating the performance and product accuracy.

Metacognitive awareness in reading comprehension is concerned with readers' conscious awareness of strategic reading processes, reading strategy repertoires, and actual utilization of reading strategies to maximize text comprehension (Carrel et al., 1998; Forrest-Pressley \& Waller, 1984; Sheorey \& Mokhtari, 2001; Zhang, 2001). Reading comprehension is a metacognitive process in which many strategies, as Alexander and Jetton (2000) asserted, are "procedural, purposeful, effortful, willful, essential, and facilitative in nature" (p. 295). While applying metacognitive strategies, readers devote more attention to controlling, monitoring, and evaluating reading process (Pressley, 2000; Pressley et al., 1995). Readers with stronger metacognitive awareness are able to interpret reading tasks more effectively in terms of context requirements. Effective readers select particular 
strategies relevant to reading purposes, task demands, and preferred cognitive styles. They monitor the process of comprehension, evaluate the effects of selected strategies, and change the strategies where necessary (Cohen, 1998; Hudson, 2007; Paris et al., 1994; Pressley \& Afflerbach, 1995; Zhang, 2008).

The findings of most studies on the effect of metacognitive awareness on L2 reading have indicated variation in the strategic behavior of learners concerning their level of language proficiency (e.g., Anderson, 1991; Block, 1986; Carrell, 1989; Rasekh \& Ranjbary, 2003; Sheorey \& Mokhtari, 2001; Yang, 2002; Zhang, 2001, 2002; Zhang, et al., 2008; Zhang \& Wu, 2009). As an example, Zhang and Wu investigated the degree of metacognitive awareness of Chinese high school students in reading comprehension through the reported description of the participants. The findings revealed a positive relationship between the students' overall EFL achievement and frequency of using metacognitive strategies.

From the findings of the mentioned studies, it is inferred that language proficiency exerts substantial influence on the frequency as well as type of metacognitive strategies used by language learners, particularly in reading comprehension process. However, in many instructional programs, common strategic-based syllabuses are still used for teaching metacognitive strategies to the students at different levels of language proficiency. In other words, little attention is devoted to designing particular strategic-based syllabuses with regard to the differences in the language ability of learners. Unfortunately, due to lack of effective strategic-based instructions in many instructional reading programs, many students cannot fully comprehend the content of the materials, and the reading courses are not highly efficient. The problem is even more serious in many EAP programs in which improving reading comprehension is of primary importance.

Thus, the present study is an attempt to explore the interaction between reading proficiency and use of metacognitive strategies via reading comprehension test performance of Iranian postgraduate EAP students. The findings can be significant as the differences in the use of metacognitive strategies are systematically investigated at different levels of reading proficiency. In addition, as reading comprehension is of crucial importance in many EAP programs at the universities in many parts of the world, the findings can provide useful information helping policy makers, curriculum planners, syllabus designers, language teachers, and test designers tailor effective instructional programs, syllabuses, teaching approaches, and tests to the particular needs of the students. Analyzing the differences between more proficient and less proficient language learners in the use of metacognitive strategies can help English teachers as well as curriculum planners design effective instructional syllabuses and teaching approaches to fill the gap between learners. Moreover, the findings can remind language teachers of different factors affecting test scores, encouraging them to interpret test scores from different sides to decrease error of measurement. As the study explores the extent of relationship between metacognitive awareness and reading comprehension test performance, the findings can help language teachers to predict reading ability of their students with regard to their metacognitive strategy use.

The research questions and corresponding hypotheses are formulated as follows:

Question one: Does level of reading proficiency significantly affect the use of metacognitive strategies in reading comprehension test performance?

Question two: To what extent are metacognitive awareness and reading comprehension test performance related?

Hypothesis one: Level of reading proficiency significantly affects the use of metacognitive strategies in reading comprehension test performance.

Hypothesis two: Metacognitive awareness and reading comprehension test performance are positively related.

\section{Method}

In this section, the participants, instruments, data collection procedures, and data analysis are discussed.

\subsection{Participants}

The participants of this study were recruited from 506 Iranian postgraduate students, majoring in different academic disciplines at Islamic Azad University of Neyshabur. The students were doing EAP courses in different academic disciplines rather than languages. Based on their scores in the reading comprehension section of a TOEFL Test (Longman, 2005), the participants were divided into the three levels of high, intermediate, and low reading proficiency. The frequency and percentage of the participants across the three levels of reading proficiency are manifested in Table 1. 
Table 1. Frequency and percentage of the participants

\begin{tabular}{lllll}
\hline Level of Reading Proficiency & Frequency & Percent & Valid Percent & Cumulative Percent \\
\hline Low & 73 & 14.4 & 14.4 & 14.4 \\
Intermediate & 344 & 68.0 & 68.0 & 82.4 \\
High & 89 & 17.6 & 17.6 & 100.0 \\
Total & 506 & 100.0 & 100.0 & \\
\hline
\end{tabular}

As demonstrated in Table 1, the students at the intermediate level of reading proficiency formed the highest proportion $(68.0 \%)$. The students at the low and high levels of reading proficiency formed the smaller proportions of the accessible participants. The distribution of the participants' reading scores was close to normal distribution.

\subsection{Instruments}

The following research instruments were used to collect data in the study:

\subsubsection{Reading Comprehension Test}

A reading comprehension section of a TOEFL test was utilized in this study to assess the reading ability of the participants. The test was selected from the paper-based version of Longman TOEFL Test (2005), consisting of five reading comprehension passages, followed by 50 multiple-choice questions. The time allocated for taking the test was 55 minutes.

\subsubsection{Metacognitive Strategy Questionnaire}

A metacognitive strategy questionnaire derived from Phakiti's (2003) metacognitive strategy questionnaire was utilized in this study. The questionnaire consisted of 30 statements, contextualizing the use of the three distinct subcategories of planning, monitoring, and evaluating metacognitive strategies. The questionnaire was organized on a 5-point Likert scale, in which the participants had to indicate the frequency of using each strategy in the test-taking process through selecting one of the following adverbs of frequency:
a) never 1
b) seldom 2
c) sometimes 3
d) often 4
e) always 5

The questionnaire was piloted by a sample of 30 Iranian postgraduate students, who gave feedback to improve the questionnaire items. In addition, the questionnaire was reviewed by some professors in TEFL who gave some professional comments, based on which the probable ambiguities were removed. The reliability index of the questionnaire was calculated by using Cronbach's alpha formula. The reliability index was $(r=0.970)$, which was high and acceptable.

\subsection{Procedures}

All the participants took the reading test and responded the metacognitive strategy questionnaire successively in one session. The time allotted to take the test was 55 minutes, and the dedicated time to respond the questionnaire was 15 minutes. Prior to answering the test and questionnaire, the participants were briefed on the structures of the test and questionnaire and the way to answer them.

\subsection{Data Analysis}

The statistical procedures used in the study were Cronbach's alpha, descriptive statistics, one-way analysis of variance, regression analysis, and Pearson product moment correlation coefficient through using the 18th version of SPSS software.

\section{Results}

The findings of this study are reported in the two subsections.

\subsection{Relationship between Level of Reading Proficiency and Metacognitive Strategies}

To explore the first research question concerning the relationship between the participants' level of reading proficiency and using metacognitive strategies, the descriptive statistics were calculated. The results are presented in Table 2. 
Table 2. Descriptive statistics for using metacognitive strategies by the three groups of proficiency

\begin{tabular}{|c|c|c|c|c|c|c|c|c|c|}
\hline \multirow[t]{2}{*}{ Strategies } & \multicolumn{5}{|l|}{ Proficiency } & \multicolumn{4}{|c|}{$\begin{array}{l}95 \% \text { Confidence } \\
\text { Interval for Mean }\end{array}$} \\
\hline & Level & $\mathrm{N}$ & Mean & $\begin{array}{l}\text { Std. } \\
\text { Deviation }\end{array}$ & $\begin{array}{l}\text { Std. } \\
\text { Error }\end{array}$ & $\begin{array}{l}\text { Lower } \\
\text { Bound }\end{array}$ & $\begin{array}{l}\text { Upper } \\
\text { Bound }\end{array}$ & Min. & Max. \\
\hline \multirow{4}{*}{$\begin{array}{l}\text { Overall } \\
\text { metacognitive } \\
\text { strategies }\end{array}$} & Low & 73 & 3.4341 & .48795 & .05711 & 3.3203 & 3.5480 & 2.34 & 4.31 \\
\hline & $\begin{array}{l}\text { Intermediat } \\
\mathrm{e}\end{array}$ & 344 & 3.5235 & .52003 & .02804 & 3.4684 & 3.5787 & 2.19 & 4.97 \\
\hline & High & 89 & 3.6592 & .49429 & .05239 & 3.5551 & 3.7633 & 2.50 & 4.69 \\
\hline & Total & 506 & 3.5345 & .51427 & .02286 & 3.4896 & 3.5794 & 2.19 & 4.97 \\
\hline \multirow[t]{4}{*}{ Planning strategies } & Low & 73 & 3.3074 & .59328 & .06944 & 3.1690 & 3.4458 & 1.80 & 4.47 \\
\hline & $\begin{array}{l}\text { Intermediat } \\
\mathrm{e}\end{array}$ & 344 & 3.4014 & .56782 & .03061 & 3.3412 & 3.4616 & 1.87 & 4.93 \\
\hline & High & 89 & 3.5639 & .53601 & .05682 & 3.4510 & 3.6768 & 2.27 & 4.67 \\
\hline & Total & 506 & 3.4164 & .57004 & .02534 & 3.3666 & 3.4662 & 1.80 & 4.93 \\
\hline \multirow{4}{*}{$\begin{array}{l}\text { Monitoring } \\
\text { strategies }\end{array}$} & Low & 73 & 3.5199 & .53860 & .06304 & 3.3942 & 3.6455 & 2.38 & 4.83 \\
\hline & $\begin{array}{l}\text { Intermediat } \\
\mathrm{e}\end{array}$ & 344 & 3.6829 & .64237 & .03463 & 3.6148 & 3.7510 & 1.75 & 5.00 \\
\hline & High & 89 & 3.7682 & .65428 & .06935 & 3.6304 & 3.9060 & 1.75 & 4.88 \\
\hline & Total & 506 & 3.6744 & .63346 & .02816 & 3.6191 & 3.7297 & 1.75 & 5.00 \\
\hline \multirow{4}{*}{$\begin{array}{l}\text { Evaluating } \\
\text { strategies }\end{array}$} & Low & 73 & 3.5836 & .57610 & .06743 & 3.4491 & 3.7180 & 2.22 & 4.89 \\
\hline & $\begin{array}{l}\text { Intermediat } \\
\mathrm{e}\end{array}$ & 344 & 3.5844 & .65493 & .03531 & 3.5149 & 3.6538 & 1.88 & 5.00 \\
\hline & High & 89 & 3.7224 & .56203 & .05958 & 3.6040 & 3.8408 & 2.13 & 4.67 \\
\hline & Total & 506 & 3.6085 & 62966 & .02799 & 3.5535 & 3.6635 & 1.88 & 5.00 \\
\hline
\end{tabular}

As shown in Table 2, overall metacognitive strategies were used more frequently by the high proficiency test takers $(M=3.6592)$ and less frequently by the intermediate $(M=3.5235)$ and low $(M=3.4341)$ proficiency test takers. As for the three subcategories of metacognitive strategies, the mean score of using monitoring strategies was the highest $(M=3.6744)$ whereas the mean score of using planning strategies was the lowest $(M=3.4164)$ for the total participants. The high proficiency group got the highest mean scores in using overall strategies $(\mathrm{M}=$ 3.6592), monitoring strategies $(M=3.7682)$, planning strategies $(M=3.5639)$, and evaluating strategies $(M=$ 3.7224). In comparison, the low proficiency group got the lowest mean scores in using overall strategies $(\mathrm{M}=$ 3.4341), monitoring strategies $(M=3.5199)$, planning strategies $(M=3.3074)$, and evaluating strategies $(M=$ 3.5836). To probe the significant differences among the mean scores of the three groups of reading proficiency in using metacognitive strategies, a one-way analysis of variance was run. The results are presented in Table 3.

Table 3. One-way analysis of variance for using metacognitive strategies

\begin{tabular}{llllllll}
\hline Strategies & & \multicolumn{2}{l}{ Sum of } & \multicolumn{2}{l}{ Mean } & & \\
& & Squares & df & Square & F & Sig. \\
\hline Overall metacognitive strategies & Between & 2.161 & 2 & 1.081 & 4.137 & .017 \\
& Groups & & & & & \\
& Within Groups & 131.400 & 503 & .261 & & \\
& Total & 133.562 & 505 & & & \\
Planning strategies & Between & 2.882 & 2 & 1.441 & 4.496 & .012 \\
& Groups & & & & & \\
& Within Groups & 161.214 & 503 & .321 & & & \\
& Total & 164.096 & 505 & & & & \\
& & & & & &
\end{tabular}




\begin{tabular}{lllllll}
\hline Monitoring strategies & Between & 2.551 & 2 & 1.276 & 3.207 & .041 \\
& Groups & & & & & \\
& Within Groups & 200.091 & 503 & .398 & & \\
Total & 202.642 & 505 & & & \\
Evaluating strategies & Between & 1.400 & 2 & .700 & 1.771 & .171 \\
& Groups & & & & & \\
& Within Groups & 198.817 & 503 & .395 & & \\
& Total & 200.216 & 505 & & & \\
\hline
\end{tabular}

As manifested in Table 3, significant differences were found among the mean scores of the three proficiency groups in using overall metacognitive strategies $\mathrm{F}(2,503)=4.137, \mathrm{p}=.017$; planning strategies $\mathrm{F}(2,503)=$ $4.496, p=.012$; monitoring strategies $F(2,503)=3.207, p=041$. No significant differences were found among the mean scores of the three groups in applying evaluating strategies $F(2,503)=1.771, \mathrm{p}=.171$.

To compare the mean differences in pairs, a Tukey HSD test was run. The results are presented in Table 4.

Table 4. Multiple comparisons between the mean scores of the three proficiency groups

\begin{tabular}{|c|c|c|c|c|c|c|c|}
\hline \multirow[b]{2}{*}{$\begin{array}{l}\text { Dependent } \\
\text { Variable }\end{array}$} & \multirow{2}{*}{$\begin{array}{l}\text { (I) } \\
\text { Reading } \\
\text { level }\end{array}$} & \multirow{2}{*}{$\begin{array}{l}(\mathrm{J}) \\
\text { Reading } \\
\text { level }\end{array}$} & \multirow{2}{*}{$\begin{array}{l}\text { Mean } \\
\text { Difference } \\
\text { (I-J) }\end{array}$} & \multirow[b]{2}{*}{$\begin{array}{l}\text { Std. } \\
\text { Error }\end{array}$} & \multirow[b]{2}{*}{ Sig. } & \multicolumn{2}{|c|}{$\begin{array}{l}95 \% \text { Confidence } \\
\text { Interval }\end{array}$} \\
\hline & & & & & & $\begin{array}{l}\text { Lower } \\
\text { Bound }\end{array}$ & $\begin{array}{l}\text { Upper } \\
\text { Bound }\end{array}$ \\
\hline \multirow[t]{6}{*}{$\begin{array}{l}\text { Metacognitive } \\
\text { strategies }\end{array}$} & Low & $\begin{array}{l}\text { Intermedia } \\
\text { te }\end{array}$ & -.08944 & .06586 & .364 & -.2443 & .0654 \\
\hline & & High & $-.22510^{*}$ & .08071 & .015 & -.4148 & -.0354 \\
\hline & Intermedia & Low & .08944 & .06586 & .364 & -.0654 & .2443 \\
\hline & te & High & -.13567 & .06078 & .067 & -.2785 & .0072 \\
\hline & High & Low & $.22510^{*}$ & .08071 & .015 & .0354 & .4148 \\
\hline & & $\begin{array}{l}\text { Intermedia } \\
\text { te }\end{array}$ & .13567 & .06078 & .067 & -.0072 & .2785 \\
\hline \multirow[t]{6}{*}{$\begin{array}{l}\text { Planning } \\
\text { strategies }\end{array}$} & Low & $\begin{array}{l}\text { Intermedia } \\
\text { te }\end{array}$ & -.09400 & .07295 & .402 & -.2655 & .0775 \\
\hline & & High & $-.25654^{*}$ & .08940 & .012 & -.4667 & -.0464 \\
\hline & Intermedia & Low & .09400 & .07295 & .402 & -.0775 & .2655 \\
\hline & te & High & $-.16254^{*}$ & .06733 & .043 & -.3208 & -.0043 \\
\hline & High & Low & $.25654^{*}$ & .08940 & .012 & .0464 & .4667 \\
\hline & & $\begin{array}{l}\text { Intermedia } \\
\text { te }\end{array}$ & $.16254^{*}$ & .06733 & .043 & .0043 & .3208 \\
\hline \multirow[t]{6}{*}{$\begin{array}{l}\text { Monitoring } \\
\text { strategies }\end{array}$} & Low & $\begin{array}{l}\text { Intermedia } \\
\text { te }\end{array}$ & -.16304 & .08128 & .112 & -.3541 & .0280 \\
\hline & & High & $-.24834^{*}$ & .09959 & .035 & -.4825 & -.0142 \\
\hline & Intermedia & Low & .16304 & .08128 & .112 & -.0280 & .3541 \\
\hline & te & High & -.08530 & .07501 & .492 & -.2616 & .0910 \\
\hline & High & Low & $.24834^{*}$ & .09959 & .035 & .0142 & .4825 \\
\hline & & $\begin{array}{l}\text { Intermedia } \\
\text { te }\end{array}$ & .08530 & .07501 & .492 & -.0910 & .2616 \\
\hline \multirow[t]{2}{*}{$\begin{array}{l}\text { Evaluating } \\
\text { strategies }\end{array}$} & Low & $\begin{array}{l}\text { Intermedia } \\
\text { te }\end{array}$ & -.00080 & .08102 & 1.000 & -.1912 & .1896 \\
\hline & & High & -.13880 & .09928 & .343 & -.3722 & .0946 \\
\hline
\end{tabular}




\begin{tabular}{llllllll}
\hline & Intermedia & Low & .00080 & .08102 & 1.000 & -.1896 & .1912 \\
te & High & -.13800 & .07477 & .156 & -.3138 & .0378 \\
& High & Low & .13880 & .09928 & .343 & -.0946 & .3722 \\
& & Intermedia & .13800 & .07477 & .156 & -.0378 & .3138 \\
& & & & & & & \\
$\mathrm{p} \leq 0.05$ & & & & & & & \\
\hline
\end{tabular}

As presented in Table 4, significant differences were found between the high and low proficiency groups in the use of metacognitive strategies ( $\left.\mathrm{I}-\mathrm{J}=.22510^{*}, \mathrm{p}=.015\right)$ and monitoring strategies $\left(\mathrm{I}-\mathrm{J}=.24834^{*}, \mathrm{p}=.035\right)$. As for planning strategies, significant differences were found between the high and low proficiency groups ( $\mathrm{I}-\mathrm{J}$ $\left.=.25654^{*}, \mathrm{p}=.012\right)$ as well as the high and intermediate groups $\left(\mathrm{I}-\mathrm{J}=.16254^{*}, \mathrm{p}=.043\right)$. No significant differences were found among the mean scores of the three groups in using evaluating strategies.

\subsection{Relationship between Metacognitive Awareness and Reading Test Performance}

To probe the second research question concerning the extent to which the participants' metacognitive awareness and reading test performance are related, a linear regression analysis was applied. The summary of the model is shown in Table 5.

Table 5. Model summary for regression analysis

\begin{tabular}{lllll}
\hline Model & $\mathrm{R}$ & $\mathrm{R}$ Square & Adjusted R Square & Std. Error of the Estimate \\
\hline 1 & $.113^{\mathrm{a}}$ & .013 & .011 & 8.41652 \\
\hline
\end{tabular}

As shown in Table 5, the bivariate correlation between using metacognitive strategies and the participants' test performance was $(\mathrm{R}=.113)$. The $\mathrm{R}$ square value $(\mathrm{R}$ square $=.013)$ indicate that $13 \%$ of the variance in the test performance can be explained by the use of metacognitive strategies. Table 6 presents the regression coefficients between the use of metacognitive strategies and reading test performance.

Table 6. Regression coefficients between the use of metacognitive strategies and reading test performance

\begin{tabular}{|c|c|c|c|c|c|}
\hline \multirow[b]{2}{*}{ Model } & \multicolumn{2}{|c|}{$\begin{array}{l}\text { Unstandardized } \\
\text { Coefficients }\end{array}$} & \multicolumn{2}{|l|}{$\begin{array}{l}\text { Standardized } \\
\text { Coefficients }\end{array}$} & \multirow[b]{2}{*}{ Sig. } \\
\hline & B & Std. Error & Beta & $\mathrm{t}$ & \\
\hline (Constant) & 14.977 & 2.601 & & 5.758 & .000 \\
\hline Metacognitive strategies & 1.859 & .728 & .113 & 2.552 & .011 \\
\hline
\end{tabular}

As revealed in Table 6, the standardized coefficient between using metacognitive strategies and the test performance was $($ Beta $=.113)$ at $\mathrm{p}=.011$, indicating a positive relationship between using metacognitive strategies and the test performance. The unstandardized regression coefficient between metacognitive strategies and test performance was 1.859 , indicating that for every one increase on the horizontal axis, the score on the vertical axis changes by 1.859 . The linear regression equation between the participants' test performance or test score, as the dependent variable, and the use of metacognitive strategies, as the independent variable, is formulated as the following,

$$
\text { Test score (true score) }=14.977+1.859 \text { (metacognitive strategies) }
$$

The equation indicates that with one increase in the use of metacognitive strategies, the test score would increase by 1.859. The constant value $(a=14.977)$ indicated the point at which the regression line cut the vertical axis.

Figure 1 demonstrates the slope of the regression line when metacognitive strategies act as independent variable and test performance or test scores act as dependent variable. 


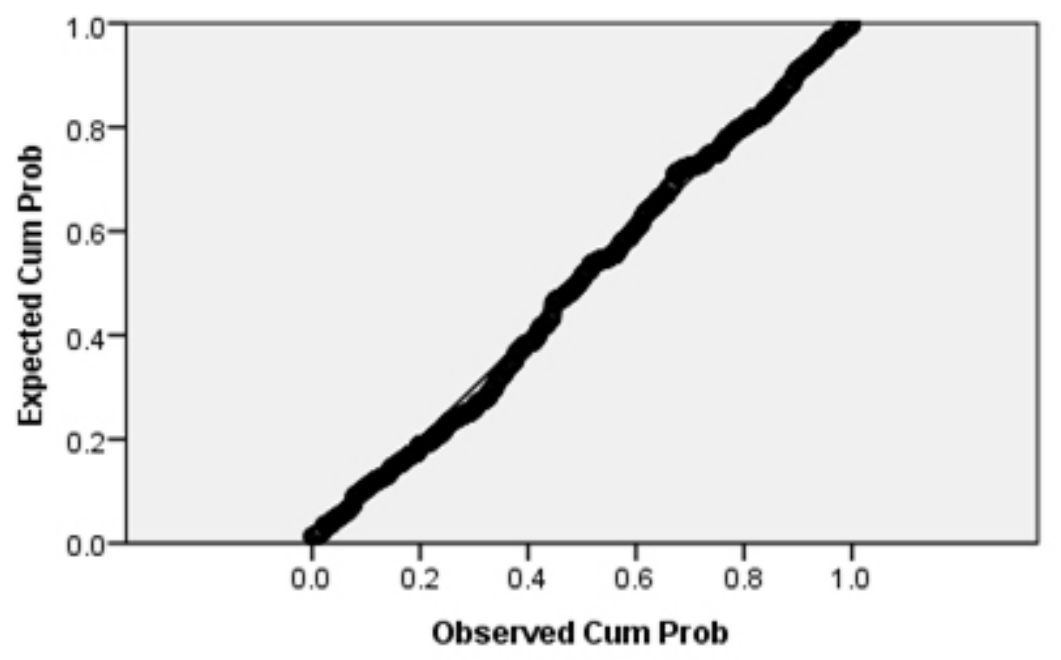

Figure 1. Regression line between metacognitive strategies and test performance

As illustrated in Figure 1, the slope of the regression line began from the bottom left up to the top right, indicating a positive relationship between metacognitive strategies and reading test performance.

In general, the findings manifest that the observed score on the test comprises two factors or two components. The first factor is the actual ability of language learners, and the second factor is the use of metacognitive strategies. As mentioned earlier, \% 13 of the variance in the test performance was due to the use of metacognitive strategies. Thus, the effect of metacognitive strategies on the test taking process cannot be ignored, and the observed scores are not reflective of the actual ability of language learners all on their own.

\section{Discussion and Conclusion}

The findings of this study reflected a significant relationship between the participants' reading ability and frequency of using metacognitive strategies. The findings pertain to the findings of the earlier studies on the relationship between metacognitive awareness and reading comprehension ability of L2 learners (e.g., Hudson, 2007; Yang, 2002; Zhang, 2001, Zhang, et al., 2008). The findings also confirmed the viewpoints of the scholars who believed that readers with stronger metacognitive awareness are able to interpret a reading task more effectively through selecting metacognitive strategies based on the context requirements (e.g. Cohen, 1998; Hudson, 2007; Paris et al., 1994; Pressley \& Afflerbach, 1995; Zhang, 2008). As metacognitive strategies act as major components of strategic competence, the findings of this study can validate empirically some models of communicative language ability depicting an interaction between language ability and strategic competence (e.g. Bachman, 1990; Bachman \& Palmer, 1996, 2010; Faerch \& Kasper, 1983). The significant positive interaction found between linguistic and strategic competences reveals the essential need to insert strategic-based instruction into L2 reading programs. Strategic-based instruction is efficient if it encourages L2 readers to think about their reading processes to enhance reading efficiency.

The findings of this study manifested the importance of exploring test-taking process to make a valid judgment about the construct to be measured. The findings justify the viewpoints of Bachman (1990) and Bachman and Palmer (1996, 2010), who believed if different sources of score variation are clearly identified, reasonable inferences about the individuals' ability can be drawn. The findings revealed that the use of metacognitive strategies in the test-taking process was one essential source of score variation. Thus, detailed analysis of test takers' metacognitive awareness provides useful insights into the complex nature of test-taking process leading to sound judgments about test takers' actual language ability. The detailed analysis of metacognitive strategies clarifies the complicated nature of strategic competence as the most essential but elusive component of communicative language ability. Therefore, any new insights into the nature of strategic competence substantially contribute to a better understanding of the other contributing components of language use.

The findings can help language teachers and test designers gain a better understanding of linguistic and strategic aspects of test-taking process and improve the design and validity of the tests. The findings can help language teachers interpret test scores with great care to make a sound judgment about the actual language ability of language learners with regard to the factors affecting test performance, particularly metacognitive awareness. The systematic investigation into the strategic patterns of L2 learners at different levels of reading ability can reveal the 
strategic gap between more proficient and less proficient language learners recommending language teachers to tailor appropriate instructional programs to meet the learners' needs. Thus, language teachers should take teacher-researcher role to improve reading ability of L2 learners through designing the best instructional programs and the appropriate remedial ways to fill the gap between more proficient and less proficient learners. Language teachers can design remedial courses and supplementary materials to improve the reading ability of less proficient learners.

\section{References}

Alexander, P. A., \& Jetton, T. L. (2000). Learning from text: A multidimensional and developmental perspective. In M. L. Kamil, P. B. Mosenthal, P. D. Pearson, \& R. Barr (Eds.), Handbook of reading research (Vol. 3, p. 295). Mahwah, NJ: Erlbaum.

Anderson, N. J. (1991). Individual differences in strategy use in second language reading and testing. Modern Language Journal, 75, 460-472. http://dx.doi.org/10.1111/j.1540-4781.1991.tb05384.x

Bachman, L. F. (1990). Fundamental considerations in language testing. Oxford: Oxford University Press.

Bachman, L. F., \& Palmer, A. S. (1996). Language testing in practice. Oxford: Oxford University Press.

Bachman, L. F., \& Palmer, A. S. (2010). Language assessment in practice. Oxford: Oxford University Press.

Block, E. L. (1986). The comprehension strategies of second language readers. TESOL Quarterly, 20, 463-494. http://dx.doi.org/10.2307/3586295

Brantmeier, C. (2002). Second language reading strategy research at the secondary and university levels: Variations, disparities, and generalizability. The Reading Matrix, 2, 1-14.

Canale, M. (1983). From communicative competence to communicative language pedagogy. In J. C. Richards, \& R. W. Schmidt (Eds.), Language and communication. New York: Longman.

Canale, M., \& Swain, M. (1980). Theoretical bases of communicative approaches to second language teaching and testing. Applied Linguistics, 1(1), 1-47. http://dx.doi.org/10.1093/applin/I.1.1

Carrell P. L., Gajdusek, L., \& Wise, T. (1998). Metacognition and ESL/EFL reading. Instructional Science: An International Journal of the Learning Sciences, 26, 97-112. http://dx.doi.org/10.1023/A:1003092114195

Carrell, P. L. (1989). Metacognitive awareness and second language reading. The Modern Language Journal, 73, 121-134. http://dx.doi.org/10.1111/j.1540-4781.1989.tb02534.x

Cohen, A. D., \& Dörnyei, Z. (2002). Focus on the language learner: Motivation styles, and strategies. In N. Schmitt (Ed.), An Introduction to applied linguistics (pp. 170-190). London: Arnold.

Cohen, A. D. (1998). Strategies and processes in test taking and SLA. In L. F. Bachman, \& A. C., Cohen (Eds.), Interfaces between second language acquisition and language testing research (pp. 90-111). Cambridge: Cambridge University Press.

Dreyer, C., \& Oxford, R. (1996). Prediction of ESL proficiency among Afrikaans-speakers in South Africa. In R. Oxford (Ed.), Language learning strategies around the World: Cross-cultural Perspectives. Second Language Teaching and Curriculum Center, University of Hawaii: Honolulu.

Faerch, C., \& Kasper, G. (1983). Strategies in interlanguage communication. London: Longman.

Forrest Pressley, D., \& Waller, T. G. (1984). Cognition, metacognition, and reading. New York: Springer-Verlag. http://dx.doi.org/10.1007/978-1-4612-5252-8

Hudson, T. (2007). Teaching second language reading. Oxford, England: Oxford University Press.

Liontas, J. (2002). Transactional idiom analysis: Theory and practice. Journal of Language and Linguistics, 1 , $17-52$.

Paris, S. G., Lipson, M. Y., \& Wixson, K. K. (1994). Becoming strategic readers. In R. B. Ruddell, M. R. Ruddell, \& H. Singer (Eds.), Theoretical models and processes of reading (pp. 788-810). Newark, DE: International Reading Association.

Peacock, M., \& Ho, B. (2003). Student language learning strategies across eight disciplines. International Journal of applied Linguistics, 13, 179-200. http://dx.doi.org/10.1111/1473-4192.00043

Phakiti, A. (2003). A closer look at the relationship of cognitive and metacognitive strategy use to EFL reading comprehension test performance. Language Testing, 20, 26-56. http://dx.doi.org/10.1191/02655322031t243oa 
Pressley, M. (2000). What should comprehension instruction be the instruction of? In M. L. Kamil, P. B. Mosenthal, P. D. Pearson, \& R. Barr (Eds.), Handbook of reading research (Vol. 3, pp. 545-561). Mahwah, NJ: Erlbaum.

Pressley, M., \& Afflerbach, P. (1995). Verbal protocols of reading: The nature of constructively responsive reading. Hillsdale, NJ: Lawrence Erlbaum.

Pressley, M., Brown, R., El-Dinary, P. B., \& Afflerbach, P. (1995). The comprehension instruction that students need: Instruction fostering constructively responsive reading. Learning Disabilities Research and Practice, $10,215-224$.

Purpura, J. E. (1997). An analysis of the relationships between test takers' cognitive and metacognitive strategy use and second language test performance. Language Learning, 47, 289-325. http://dx.doi.org/10.1111/0023-8333.91997009

Rasekh, A. E., \& Ranjbary, R. (2003). Metacognitive strategy training for vocabulary learning. TESL-EJ, 7(2).

Saricoban, A. (2002). Reading strategies of successful readers through the three phase approach. The Reading Matrix, 2, 1-13.

Scarcella, R., \& Oxford, R. (1992). The tapestry of language learning: The individual in the communicative classroom. Boston: Heinle and Heinle.

Sheorey, R., \& Mokhtari, K. (2001). Differences in the metacognitive awareness of reading strategies among native and non-native readers. System, 29(4), 431-449. http://dx.doi.org/10.1016/S0346-251X(01)00039-2

Shrum, J. L., \& Glisan, E. W. (2000). Teacher's handbook. Boston: Heinle and Heinle.

Singhal, M. (2001). Reading proficiency, reading strategies, metacognitive awareness and L2 readers. The Reading Matrix, 1, 1-9.

Sternberg, R. J. (1985). Beyond IQ: A triarchic theory of human intelligence. New York: Cambridge University Press. http://dx.doi.org/10.1023/A:1003096215103

Sternberg, R. J. (1998). Metacognition, abilities, and developing expertise: What makes an expert student? Instructional Science, 26, 127-140.

$\mathrm{Su}, \mathrm{M}$. (2005). A study of EFL technological and vocational college students' language learning and their self-perceived English proficiency. Electronic Journal of Foreign Language Teaching, 2(1). Retrieved from http://e-flt.nus.edu.sg/Nation.

Yang, Y. F. (2002). Reassessing readers' comprehension monitoring. Reading in a Foreign Language, 14(1), $18-42$.

Zhang, L. J., \& Wu, J. (2009). Chinese senior high school EFL students' metacognitive awareness and reading-strategy use. Reading in a Foreign Language, 21(1).

Zhang, L. J. (2001). Awareness in reading: EFL students' metacognitive knowledge of reading strategies in an acquisition-poor environment. Language Awareness, $10, \quad$ 268-288. http://dx.doi.org/10.1080/09658410108667039

Zhang, L. J. (2002). Exploring EFL reading as a metacognitive experience: Reader awareness and reading performance. Asian Journal of English Language Teaching, 12, 65-90.

Zhang, L. J. (2008). Constructivist pedagogy in strategic reading instruction: Exploring pathways to learner development in the English as a second language (ESL) classroom. Instructional Science: An International Journal of the Learning Sciences, 36, 89-116. http://dx.doi.org/10.1007/s11251-007-9025-6

Zhang, L. J., Gu, Y. P., \& Hu, G. (2008). A cognitive perspective on Singaporean bilingual children's use of reading strategies in learning to read in English. British Journal of Educational Psychology, 78, $245-271$. http://dx.doi.org/10.1348/000709907X218179

\section{Copyrights}

Copyright for this article is retained by the author(s), with first publication rights granted to the journal.

This is an open-access article distributed under the terms and conditions of the Creative Commons Attribution license (http://creativecommons.org/licenses/by/3.0/). 